\title{
Construção de uma sequência didática sobre química dos solos usando a metodologia STEM: Análise das competências da BNCC e dos elementos da abordagem CTS
}

Construction of a didatic sequence about soil chemistry using STEM methodology: Analysis of BNCC skills and elements STS approach

Producción de una secuencia didáctica sobre química del suelos usando a metodologia STEM: Análisis de habilidades BNCC y elementos del enfoque CTS

\section{Resumo}

Sequências didáticas (SD) podem ser definidas como um conjunto de atividades escolares organizadas, de maneira sistemática, em torno de um gênero textual oral ou escrito. Neste contexto, este trabalho visa a construção de uma SD tendo como tema principal química dos solos e o uso da agricultura sintrópica para crianças do ensino fundamental. O presente trabalho foi aprovado e financiado pela PROEX-UNIFEI, sendo vinculado ao projeto "Semeando Cientistas" que visa a popularização da ciência para crianças em situação de vulnerabilidade socioeconômica. Utilizou-se da metodologia de ensino STEM (do inglês, Science, Technology, Engeneering and Math) e da abordagem Ciência, Tecnologia e Sociedade (CTS) para a construção da SD que é dividida em 9 etapas e 10 aulas separadas pelo intervalo de uma semana. A SD apresenta um projeto principal (construção de uma horta na escola) e atividades complementares que buscam fazer com que as crianças estejam aptas a resolver uma questão principal considerada no trabalho como "dilema". Estudou-se as competências da Base Nacional Comum Curricular (BNCC) e a relação entre a metodologia STEM e a abordagem CTS para promoção de um processo de ensino-aprendizagem mais contextualizado. Além disso, analisou-se como os elementos de ciência, tecnologia e sociedade são apresentados na SD.

Palavras-chave: BNCC; Química do solo; CTS; STEM; Ensino fundamental.

\begin{abstract}
Didatic sequences (DS) can be defined as a set of school activities organized, in a systematic way, around an oral or written textual genre. In this context, this work aims to build an DS with the main theme of soil chemistry and the use of syntropic agriculture for elementary school children. This work was approved and financed by PROEX-UNIFEI, being linked to the project "Semeando Cientistas" which aims to popularize science for children in socioeconomic vulnerability situations. We used the STEM methodology (Science, Technology, Engeneering and Math) and the Science, Technology and Society (STS) approach to build DS, which is divided into 9 stages and 10 classes separated by an interval week. DS presents a main project (building a vegetable garden at school) and complementary activities that seek to make children able to solve a main issue considered at work as a "dilemma". The competencies of the National Common Curricular Base (NCCB) and the relationship between STEM methodology and STS approach were studied to promote a more contextualized teaching-learning process. In addition, it was analyzed how the elements of science, technology and society are presented in the SD.
\end{abstract}

Keywords: NCCB; Soil chemistry; STS; STEM; Elementary school children.

\section{Resumen}

Secuencias didácticas (SD) pueden definirse como un conjunto de actividades escolares organizadas, de forma sistemática, en torno a un género textual oral o escrito. En este contexto, este trabajo tiene como objetivo construir uma SD con el tema principal de la química del suelo y el uso de la agricultura sintropica para los niños de la escuela 
primaria. Este trabajo fue aprobado y financiado por PROEX-UNIFEI, estando vinculado al proyecto "Semeando Cientistas" que tiene como objetivo divulgar la ciencia para niños en situación de vulnerabilidad socioeconómica. Usamos la metodología de enseñanza STEM (del inglés, Science, Technology, Engeneering and Math) y el enfoque de ciencia, tecnología y sociedad (CTS) para construir una SD, que se divide en 9 etapas y 10 clases separadas por una semana de intervalo. La SD presenta un proyecto principal (construcción de un huerto en la escuela) y actividades complementarias que buscan que los niños sean capaces de resolver un problema principal considerado en el trabajo como un "dilema". Se estudiaron las competencias de la Base Curricular Común Nacional (BNCC) y la relación entre la metodología STEM y el enfoque CTS para promover un proceso de enseñanza-aprendizaje más contextualizado. Además, se analizó cómo se presentan en el SD los elementos de ciencia, tecnología y sociedad.

Palabras clave: BNCC; Química del suelo; CTS; STEM; Escuela primaria.

\section{Introdução}

Uma sequência didática (SD) pode ser definida segundo os trabalhos de Dolz e colaboradores (2004), como "um conjunto de atividades escolares organizadas, de maneira sistemática, em torno de um gênero textual oral ou escrito". Em geral, o esquema de uma SD envolve uma apresentação da situação com uma produção inicial, o desenvolvimento da SD através de módulos e a conclusão da SD com uma produção final.

A apresentação da situação envolve uma descrição detalhada da tarefa que os alunos irão realizar, fornecendo uma base para que eles consigam desenvolver uma produção inicial que irá servir como parâmetro para as adaptações que o professor deve fazer à SD para que ela se encaixe à realidade dos alunos. Os módulos são a forma de se aprofundar no tema da SD para que na produção final o aluno consiga colocar em prática os conhecimentos adquiridos e o professor consiga mensurar os progressos alcançados (Dolz, et. al., 2004).

Em geral, o ensino brasileiro atualmente é preso a modelos tradicionais de ensino em que o estudante atua como receptor de informação e o professor como sua fonte. Por conta disso, alguns pesquisadores da área de educação em ciências estudam caminhos teórico-metodológicos para um ensino mais motivador e vinculado à realidade dos estudantes, como pontuado por Santos e Mortimer (2001).

A Base Nacional Comum Curricular (BNCC) é um documento que regulamenta quais são as aprendizagens essenciais a serem trabalhadas nas escolas brasileiras públicas e particulares de educação infantil, ensino fundamental e ensino médio para garantir o direito à aprendizagem e o desenvolvimento pleno de todos os estudantes (Instituto Ayrton Senna, 2018). Atualmente, a BNCC dá destaque ao desenvolvimento de competências linguísticas que estão em estreita relação com o uso das novas tecnologias e sua aplicação na vida prática, abrindo espaço para que as escolas trabalhem o protagonismo do aluno e sua ética, fazendo-o valorizar práticas sociais (Francisco, 2018).

Nesse sentido, diferentes metodologias têm sido estudadas visando a compreensão das competências da BNCC e a superação do ensino tradicional. Dentre as metodologias que podem ser propostas, pode-se destacar o ensino STEM (do inglês, Science, Technology, Engeneering and Math), a qual é uma proposta norte-americana e pode ser utilizada no contexto da educação brasileira (Carnevale, Smith \& Melton, 2011), e a abordagem Ciência, Tecnologia e Sociedade (CTS).

O ensino STEM, conforme definido por Breiner e colaboradores (2012), "pode ser uma variedade de atividades, mas, de modo geral, inclui a substituição das estratégias tradicionais de ensino baseadas em palestras por mais pesquisas e abordagens baseadas em projetos". Esses projetos englobam resolução de situações problemas que envolvem conceitos de ciências, tecnologia, engenharia e matemática. O aluno formado em STEM desenvolve-se como um solucionador de problemas, tecnologicamente alfabetizado e pensador lógico, sendo capaz de relacionar a sua cultura com o aprendizado (Morrison, 2006).

Um currículo com abordagem CTS apresenta como principal objetivo o desenvolvimento da tomada de decisão pelos alunos, sendo uma integração entre educação científica, tecnológica e social. Na abordagem CTS, conteúdos históricos e socioeconômicos são estudados juntamente com a integração científica e tecnológica, incorporando o desenvolvimento de 
valores de interesse coletivo como solidariedade, consciência de compromisso social e de respeito ao próximo (Santos, 2007).

Segundo Firme e colaboradores (2011), a ciência numa abordagem CTS deve ser "compreendida como uma construção humana e inserida num contexto sociocultural, que gera conhecimentos condicionados por interesses diversos", a tecnologia deve ser "compreendida a partir da aplicação de conhecimentos (científicos ou não) para satisfazer as necessidades humanas, e que contribui para a construção de novos conhecimentos" enquanto a sociedade deve ser "compreendida como um sistema estruturado de relações sociais, no qual se compartilha uma cultura científico-tecnológica e que deve tomar parte na constituição e aplicação do conhecimento científico e tecnológico".

Nesse contexto, um currículo que apresenta abordagem CTS ao mesmo tempo que se utiliza da metodologia STEM para a resolução de situações problemas pode gerar um aprendizado mais relevante para os alunos e inserir conteúdos científicos dentro da realidade deles, contribuindo para um ensino de química mais significativo e crítico devido a uma maior diversificação do ensino.

A química dos solos é um conteúdo científico pouco trabalhado em salas de aulas, entretanto sua discussão pode ser uma ferramenta aplicável para discussão de questões ambientais, sociais, tecnológicas e científicas, relacionando-se com a abordagem CTS por se introduzir um ambiente em que se permite a discussão de avanços científicos e tecnológicos, assim como suas implicações no ambiente (Santos \& Mortimer, 2000). Ao se introduzir na cadeia das interrelações CTS as implicações ambientais, tem-se o que se chama de abordagem CTSA (ciência-tecnologia-sociedade-ambiente) (Santos, 2007). Uma forma de se introduzir essa discussão pode ser por meio de projetos que envolvem, por exemplo, a construção de hortas nas escolas conforme trabalho realizado por Souza e colaboradores (2018).

A construção de hortas nas escolas é uma prática que permite a discussão da abordagem CTS/CTSA, assim como contribui para promoções da saúde, alimentação saudável e preservação do meio ambiente (Souza \& Nunes, 2018) e discussões sobre o uso de agrotóxicos (Cribb, 2010). Uma forma de se trabalhar essa prática é por meio da introdução de conceitos de agricultura sintrópica que é definida por Baleeiro e colaboradores (2018) como "uma cosmovisão que abrange uma forma de agricultura, intitulada agroflorestal sucessional, que prevê a recuperação pelo uso agrícola da área, contrariando a lógica da agricultura industrial que exaure os recursos do solo que utiliza. É considerada uma agricultura de processos e não de insumos", ou seja, compreende-se no plantio de hortaliças utilizando apenas o que as plantas tem a oferecer (Peneireiro, 1999).

Trabalhos como os de Ramalho Júnior e colaboradores (2020), propõem o desenvolvimento de uma sequência didática baseada na abordagem CTS/CTSA propondo a construção de uma horta com os conceitos de sintropia e destinando-se a alunos do $2^{\circ}$ ano do ensino médio. O trabalho desenvolvido por Ramalho Junior e colaboradores é uma variação do que é proposto no projeto Semeando Cientistas (aprovado e financiado pela Pró-Reitoria de Extensão da Universidade Federal de Itajubá e pela ONG norte-americana Leading Change Foundation) assim como o presente trabalho, entretanto, neste momento, mudou-se o foco para crianças de 11 a 14 anos e em situação de vulnerabilidade socioeconômica.

Portanto, o presente trabalho buscou o desenvolvimento de uma sequência didática destinada a crianças do ensino fundamental com base na metodologia STEM, promovendo o desenvolvimento de um projeto de construção de uma horta sintrópica na escola e a resolução de problemas que englobam essa construção. Além disso, analisou-se elementos da abordagem CTS/CTSA e as competências da BNCC presentes na SD e relacionou-os com possíveis limitações e perspectivas para o ensino de química.

\section{Metodologia}

A construção da sequência didática é vinculada ao projeto Semeando Cientistas, aprovado e financiado pela próreitoria de extensão da Universidade Federal de Itajubá (PROEX UNIFEI) e pela ONG norte-americana Leading Change Foundation. O projeto Semeando Cientistas visa a popularização da ciência para 160 crianças, com idades de 4 a 14 anos, em 
situação de vulnerabilidade aplicando a metodologia de ensino STEM no Centro de Apoio Nossa Senhora do Sagrado Coração em Itajubá-MG. Essas crianças são atendidas pelo Centro com diferentes atividades no contraturno escolar. Sendo assim, o presente trabalho é um estudo de caso realizado através de um método qualitativo (Pereira et al, 2018) que visa demonstrar a aplicação da presente SD para motivação de crianças a ingressarem em carreiras de ciências e engenharias .

Para tanto, elaborou-se uma sequência didática com tema central de química dos solos, tendo como experimento principal a construção de uma horta com os conceitos de agricultura sintrópica. A sequência didática foi destinada a crianças do ensino fundamental (11 a 14 anos), devido às competências específicas da Base Nacional Comum Curricular (BNCC) que são abordadas para serem trabalhadas até o sétimo ano do Ensino Fundamental. As unidades temáticas, os objetos de conhecimento e as habilidades que podem ser desenvolvidas ao longo da aplicação da SD estão expressas no Quadro 1.

Quadro 1: Competências da BNCC abordadas ao longo da SD.

\begin{tabular}{|c|c|c|}
\hline $\begin{array}{c}\text { UNIDADES } \\
\text { TEMÁTICAS }\end{array}$ & $\begin{array}{c}\text { OBJETOS DE } \\
\text { CONHECIMENTO }\end{array}$ & HABILIDADES \\
\hline Vida e evolução & $\begin{array}{l}\text { Seres vivos no ambiente } \\
\text { Plantas }\end{array}$ & $\begin{array}{l}\text { (EF02CI04) Descrever características de plantas e animais } \\
\text { (tamanho, forma, cor, fase da vida, local onde se desenvolvem } \\
\text { etc.) que fazem parte de seu cotidiano e relacioná-las ao ambiente } \\
\text { em que eles vivem. }\end{array}$ \\
\hline Terra e Universo & $\begin{array}{l}\text { Características da Terra } \\
\text { Observação do céu } \\
\text { Usos do solo }\end{array}$ & $\begin{array}{l}\text { (EF03CI09) Comparar diferentes amostras de solo do entorno da } \\
\text { escola com base em características como cor, textura, cheiro, } \\
\text { tamanho das partículas, permeabilidade etc. }\end{array}$ \\
\hline Vida e evolução & $\begin{array}{l}\text { Nutrição do organismo } \\
\text { Hábitos alimentares } \\
\text { Integração entre os sistemas } \\
\text { digestório, respiratório e } \\
\text { circulatório }\end{array}$ & $\begin{array}{l}\text { (EF05CI08) Organizar um cardápio equilibrado com base nas } \\
\text { características dos grupos alimentares (nutrientes e calorias) e nas } \\
\text { necessidades individuais (atividades realizadas, idade, sexo etc.) } \\
\text { para a manutenção da saúde do organismo. }\end{array}$ \\
\hline Matéria e energia & $\begin{array}{l}\text { Máquinas simples } \\
\text { Formas de propagação do calor } \\
\text { Equilíbrio termodinâmico e } \\
\text { vida na Terra } \\
\text { História dos combustíveis e das } \\
\text { máquinas térmicas }\end{array}$ & $\begin{array}{l}\text { (EF07CI06) Discutir e avaliar mudanças econômicas, culturais e } \\
\text { sociais, tanto na vida cotidiana quanto no mundo do trabalho, } \\
\text { decorrentes do desenvolvimento de novos materiais e tecnologias } \\
\text { (como automação e informatização). }\end{array}$ \\
\hline $\begin{array}{l}\text { Probabilidade } \mathrm{e} \\
\text { estatística }\end{array}$ & $\begin{array}{l}\text { Leitura e } \text { interpretação de } \\
\text { tabelas e gráficos (de colunas } \\
\text { ou barras simples ou múltiplas) } \\
\text { referentes } \\
\text { categóricas } \\
\text { numéricas }\end{array}$ & $\begin{array}{l}\text { (EF06MA32) Interpretar e resolver situações que envolvam dados } \\
\text { de pesquisas sobre contextos ambientais, sustentabilidade, } \\
\text { trânsito, consumo responsável, entre outros, apresentadas pela } \\
\text { mídia em tabelas e em diferentes tipos de gráficos e redigir textos } \\
\text { escritos com o objetivo de sintetizar conclusões. }\end{array}$ \\
\hline
\end{tabular}

Fonte: BNCC, 2018 (adaptado).

Observa-se no Quadro 1 a interdisciplinaridade entre as competências da BNCC que podem ser desenvolvidas com a aplicação da SD. O Quadro 2 apresenta informações sobre a carga horária da SD desenvolvida, quais os principais objetivos educacionais, o dilema da SD (objetivo central educacional contextualizado), assim como os conteúdos abordados, recursos didáticos e tecnologias emergentes. 
Quadro 2: Informações iniciais sobre a construção da Sequência Didática.

\begin{tabular}{|c|c|}
\hline Carga horária & $\begin{array}{l}\text { A Sequência Didática foi dividida em } 10 \text { aulas de } 50 \text { minutos cada uma ( } 8,3 \text { horas), sendo } \\
\text { considerado um intervalo de } 7 \text { dias entre cada aula. }\end{array}$ \\
\hline $\begin{array}{l}\text { Objetivos } \\
\text { Educacionais }\end{array}$ & $\begin{array}{l}\text { 1- Introduzir o conteúdo de química dos solos e fazer um elo com situações reais; } \\
\text { 2- Despertar no aluno o interesse de adquirir conhecimentos que ainda não tem para explicar } \\
\text { algumas situações; } \\
\text { 3- Promover a agricultura sintrópica como prática que pode ser que pode estimular o } \\
\text { empreendedorismo para as crianças e/ou seus familiares provendo uma pequena fonte de renda; } \\
\text { 4- Despertar o interesse por carreiras de ciências e engenharia; } \\
\text { 5- Trabalhar com práticas colaborativas para estimular a criatividade e trabalho em grupo; } \\
\text { 6- Aplicar o modelo de ensino Ciência, Tecnologia e Sociedade (CTS) para construir uma visão } \\
\text { crítica da ciência, permitindo as crianças realizarem participações na sociedade e tomadas de } \\
\text { decisões; } \\
\text { 7- Aplicar a metodologia STEM como ferramenta potencializadora do processo ensino- } \\
\text { aprendizagem. } \\
\text { 8- Estimular boas práticas alimentares. }\end{array}$ \\
\hline Dilema & $\begin{array}{l}\text { Como introduzir aos alunos uma prática sustentável que ensina boas práticas alimentares, } \\
\text { podendo ser aplicada como fonte de renda ou de sustentação, ao mesmo tempo que se insere os } \\
\text { alunos no mundo das ciências e engenharias, instigando-os a apresentarem interesse por essas } \\
\text { carreiras? }\end{array}$ \\
\hline Conteúdos abordados & $\begin{array}{l}\text { 1- Química dos Solos; } \\
\text { 2- Agricultura Sintrópica; } \\
\text { 3- Relação entre o conteúdo apresentado e carreiras de ciências e engenharias. }\end{array}$ \\
\hline
\end{tabular}

Fonte: Os autores (2021).

Buscou-se para a construção da SD a utilização da metodologia STEM e da abordagem de ensino CTS. A utilização da metodologia STEM visou unir a contextualização ao ensino de ciências e consistiu na utilização de práticas complementares (como experimentos) voltadas para o dilema: "como introduzir aos alunos uma prática sustentável que ensina boas práticas alimentares, podendo ser aplicada como fonte de renda ou de sustentação, ao mesmo tempo que se insere os alunos no mundo das ciências e engenharias, instigando-os a apresentarem interesse por essas carreiras?”, conforme apresentado no Quadro 2.

Ao longo de toda SD, os alunos e o professor sabem qual o dilema e devem usar a sequência de aulas propostas como forma de se resolver essa situação problema, em conjunto.

Além da prática principal da construção da horta com os conceitos de agricultura sintrópica, outras estratégias de ensino foram adotadas, conforme será apresentado ao longo da SD. A avaliação da SD se dará de forma processual, sendo avaliada a participação na construção das atividades propostas, apresentação de um pôster com objetivo principal de contextualizar como a ciência é divulgada e atividades como forma de verificar o quanto a visão do aluno sobre o tema discutido se desenvolveu, sendo um parâmetro qualitativo para a avaliação. No final da SD, com a finalidade de coletar dados quantitativos, destaca-se a possibilidade de aplicação da Escala Likert (Pereira et al, 2018), porém este não é o objetivo da SD que foi construída. Desenvolveu-se, neste trabalho, um estudo sobre a possibilidade da aplicação da SD à contextualização do ensino e como ferramenta para motivação de crianças em situação de vulnerabilidade socioeconômica.

O detalhamento completo da SD está apresentado à seção Resultados e Discussões, assim como a análise dos elementos da abordagem CTS e das competências da BNCC presentes nessa proposta. Foi realizada uma articulação entre as etapas da SD e o modelo de ensino referente ao trabalho de Santos e colaboradores (2000). Após a análise, discute-se a 
possibilidade de aplicação da SD como estratégia de ensino para a formação do aluno utilizando uma abordagem CTS, assim como as contribuições da metodologia de ensino STEM para o desenvolvimento da liderança e como forma de motivação dos alunos seguirem carreiras em ciências e engenharias. Além da SD elaborada, montou-se um roteiro para os alunos que será apresentado nos resultados e discussões. As principais conclusões do trabalho foram tomadas a partir das análises realizadas depois da construção da SD e considerando a potencialidade da aplicação da SD proposta.

\section{Resultados e Discussão}

\subsection{Estrutura da SD}

A Sequência Didática proposta cujo tema principal é química dos solos e o uso da agricultura sintrópica foi organizada em 9 etapas e um total de 10 aulas de 50 minutos cada, apresentando um intervalo de uma semana entre as aulas. A proposta de 10 aulas foi proposta com base na realidade das crianças do Centro de Apoio, podendo ser adaptada para menos ou mais aulas no decorrer da aplicação da SD ou de acordo com a necessidade de professores que possam vir a utilizá-la. O detalhamento da SD é apresentado no Quadro 3.

Quadro 3: Sequência didática proposta com base no tema "O uso da agricultura sintrópica como prática para o ensino de química dos solos".

\begin{tabular}{|c|c|}
\hline Aula & Desenvolvimento das atividades \\
\hline $\begin{array}{l}\text { Aula 1: Apresentação } \\
\text { da SD e ideias iniciais }\end{array}$ & $\begin{array}{l}\text { Atividade } 1 \text { - Apresentação da Sequência Didática } \\
\text { Objetivos da atividade: } \\
\text { - Introduzir o tema da sequência didática; } \\
\text { - } \quad \text { Apresentar o dilema da SD (contextualizando que no final da SD os alunos terão de responder essa questão); } \\
\text { Atividade } 2 \text { - O que é uma horta? } \\
\text { Material: } \\
\text { - Folha de sulfite e lápis de cor } \\
\text { Objetivos da atividade: } \\
\text { - Identificar concepções prévias dos alunos sobre o que é uma horta; } \\
\text { Obter um parâmetro que será utilizado no final SD como forma de avaliação da evolução dos conceitos } \\
\text { Objetivos dos estudantes: } \\
\text { - Expressar concepções prévias sobre o tema. } \\
\text { Orientações: } \\
\text { O professor deve entregar uma folha de sulfite para cada aluno e pedir para eles desenharem uma horta. Após desenharem, } \\
\text { o professor deve pedir que todos anotem o nome na folha e que a entreguem-na para ele. }\end{array}$ \\
\hline Aula 2: Nivelamento & $\begin{array}{l}\text { Atividade 1 - Apresentação de Vídeo } \\
\text { Material } \\
\text { - Vídeo "Comida que alimenta" com duração de } 4 \text { minutos e } 54 \text { segundos, disponível em: } \\
\text { <https://youtu.be/z6xAkNPV3QI>. } \\
\text { Objetivos da atividade: } \\
\text { - Iniciar a discussão sobre aspectos sociais e impactos da atividade agrícola; } \\
\text { - Nivelar todos os alunos sobre alguns conceitos que envolvem a atividade agrícola; } \\
\text { - Alertar os alunos sobre os riscos que os agrotóxicos podem causar pro meio ambiente e pra saúde; } \\
\text { - Discutir sobre o que é uma boa alimentação. } \\
\text { Objetivos dos estudantes: } \\
\text { - Entender os impactos da atividade agrícola no meio; }\end{array}$ \\
\hline
\end{tabular}




\begin{tabular}{|c|c|}
\hline & $\begin{array}{l}\text { - Entender a agricultura como uma forma de conseguir dinheiro; } \\
\text { - Entender os riscos que os agrotóxicos oferecem; } \\
\text { Aprender sobre boas práticas alimentares. } \\
\text { Orientações: } \\
\text { Após apresentação do vídeo, o professor deverá iniciar uma discussão com os alunos sobre os conceitos abordados. Um } \\
\text { roteiro que pode ser utilizado é: } \\
\text { a) Vocês sabem o que são agrotóxicos? } \\
\text { b) Comida com agrotóxicos é boa? } \\
\text { c) Que tipos de problemas o agrotóxico pode causar pro meio ambiente? E pra saúde? } \\
\text { d) Feiras orgânicas são locais que se encontra alimentos de melhor qualidade que supermercados? } \\
\text { e) Podemos usar a agricultura para conseguir dinheiro? Vocês lembram de algum exemplo do vídeo? } \\
\text { Após realizar cada pergunta, o professor deve responde-la de uma maneira mais completa como forma de introduzir o } \\
\text { tema e nivelar todos os alunos. Como recurso, o professor pode deixar o vídeo aberto, separar os trechos que se referem a } \\
\text { cada pergunta e ir passando novamente o vídeo após a realização de cada pergunta. Para o fim da aula, os estudantes } \\
\text { devem realizar uma pesquisa como tarefa de casa (não obrigatória), respondendo } 2 \text { questões: } \\
\text { a) Vocês conhecem algum parente ou alguém que cultiva hortaliças em casa? } \\
\text { b) Vocês consomem estas hortaliças em refeições ou de alguma maneira? }\end{array}$ \\
\hline $\begin{array}{l}\text { Aula } \\
\text { Apresentando } \\
\text { projeto final e o } \\
\text { plantio da hortaliça } \\
\text { experimental }\end{array}$ & 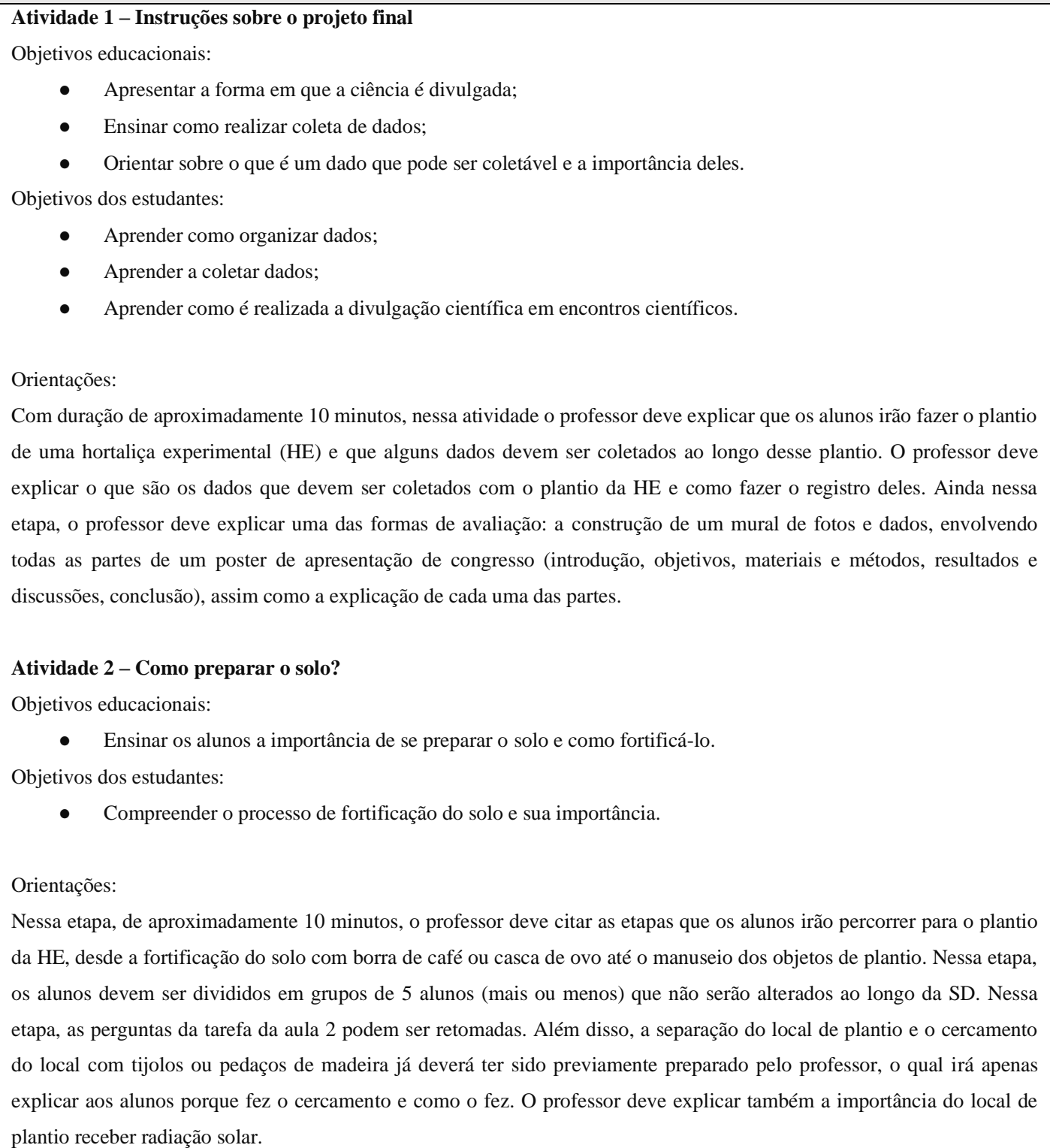 \\
\hline
\end{tabular}




\begin{tabular}{|c|c|}
\hline & $\begin{array}{l}\text { Atividade 3 - Plantio da HE } \\
\text { Objetivos educacionais: } \\
\text { - Orientar e supervisionar o plantio das hortaliças. } \\
\text { Objetivos dos estudantes: } \\
\text { - Preparar o solo; } \\
\text { - Realizar o plantio das hortaliças; } \\
\text { - Realizar o registro fotográfico dos processos como forma de primeira coleta de dados. } \\
\text { Orientações: } \\
\text { Nessa etapa, os alunos irão realizar o plantio da HE. É importante dar autonomia para os alunos realizarem todas } \\
\text { atividades e fazer o registro por meio de fotos para que eles consigam, depois, elaborar o pôster. Cada grupo ficará com } \\
\text { um plantio diferente (alface, rúcula, coentro, salsinha e repolho, por exemplo). É importante também o professor realizar o } \\
\text { plantio em um solo sem preparo para mostrar aos alunos a importância de se preparar o solo corretamente (essa etapa irá } \\
\text { gerar um dos resultados esperados pelos alunos no final da SD). O procedimento para fortificação e plantio é descrito no } \\
\text { roteiro dos alunos que será apresentado posteriormente nessa SD. }\end{array}$ \\
\hline $\begin{array}{l}\text { Aula 4: } \text { Fundamentos } \\
\text { da agricultura } \\
\text { sintrópica } \\
\text { importância do solo } \\
\text { como recurso para } \\
\text { uma vida mais } \\
\text { sustentável }\end{array}$ & 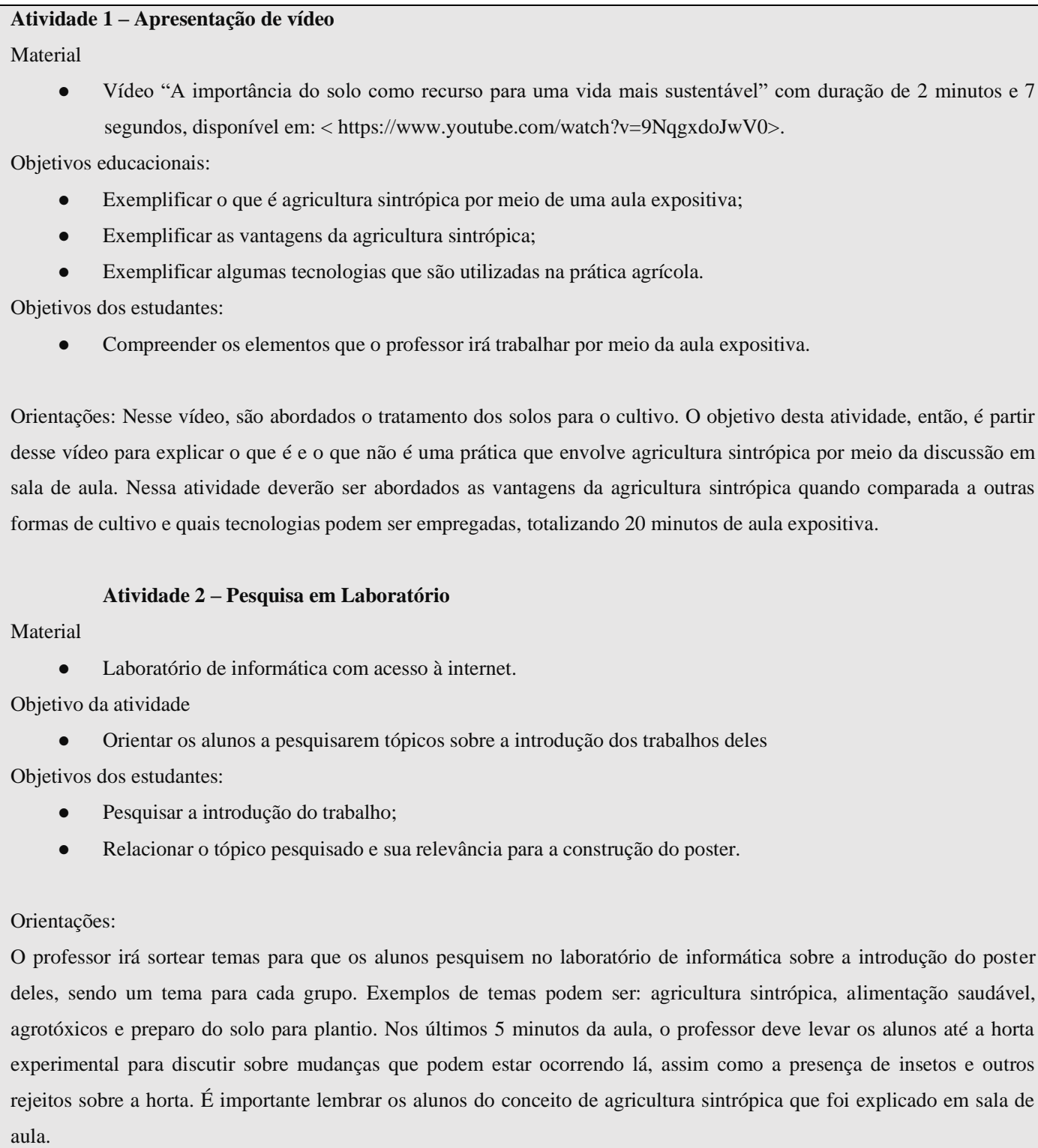 \\
\hline $\begin{array}{l}\text { Aula 5: O cientista } \\
\text { do solo e a química } \\
\text { dos solos }\end{array}$ & $\begin{array}{l}\text { Atividade } 1 \text { - Diferenças entre os tipos de solos } \\
\text { Materiais } \\
\text { - Três garrafas pets; } \\
\text { - Tesoura; }\end{array}$ \\
\hline
\end{tabular}




\begin{tabular}{|c|c|}
\hline & 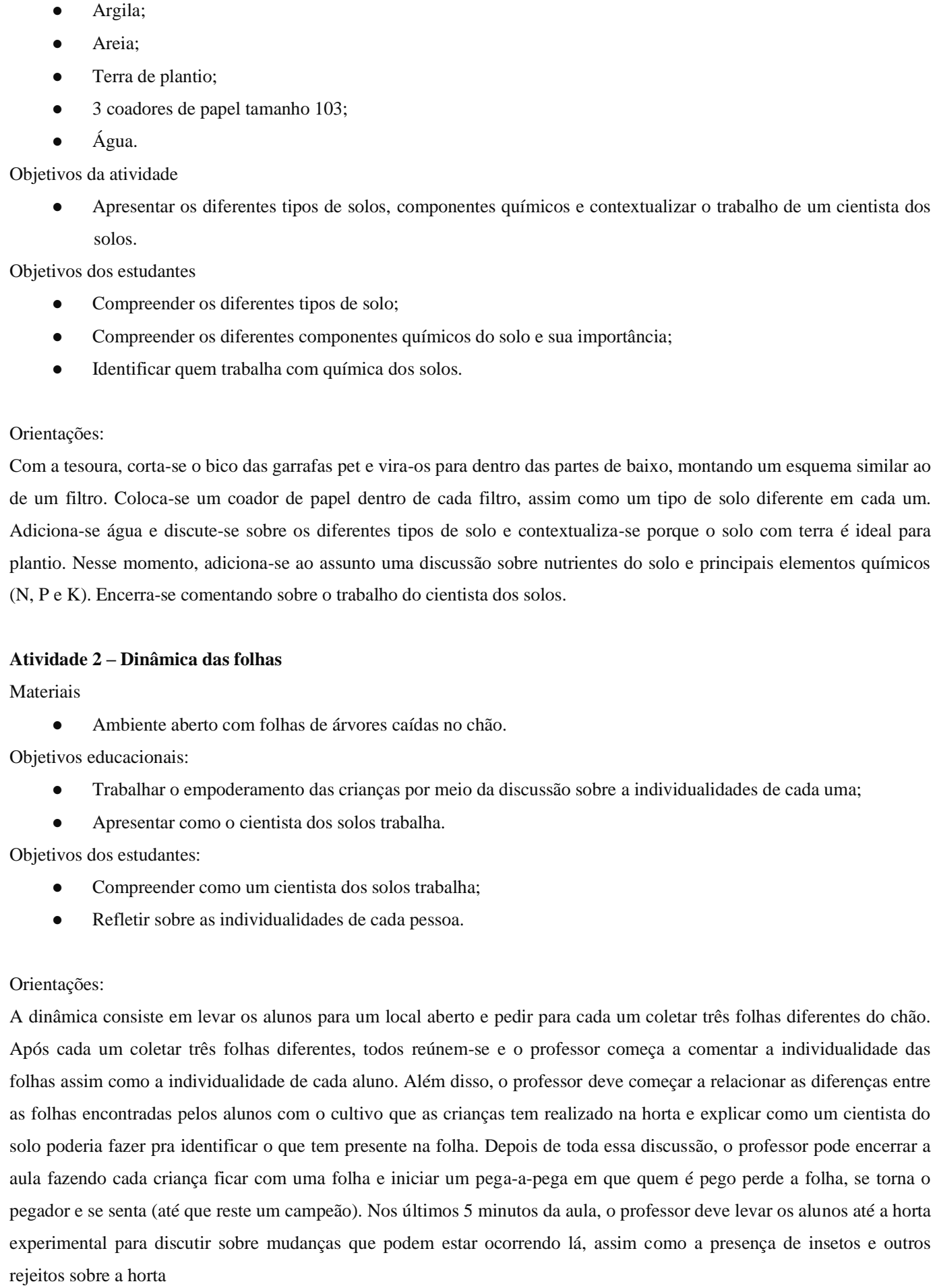 \\
\hline $\begin{array}{l}\text { Aula 6: Carreiras em } \\
\text { Ciências } \\
\text { Engenharia, } \\
\text { agricultura familiar e } \\
\text { o uso da prática } \\
\text { aprendida como } \\
\text { forma de sustento }\end{array}$ & $\begin{array}{l}\text { Atividade } 1 \text { - Carreiras em ciências e engenharia, agricultura familiar e o uso da prática aprendida como forma de } \\
\text { sustento } \\
\text { Objetivos educacionais: } \\
\text { - Apresentar possibilidades de carreiras nas áreas em ciências e engenharia que se relacionam com o tema central } \\
\text { da SD; } \\
\text { - Apresentar possibilidades de tornar o conteúdo dessa SD rentável; } \\
\text { - Contextualizar a importância do ensino de inglês para os alunos que pretendem seguir carreiras nessas áreas. } \\
\text { - Apresentar o uso de tecnologias na prática agrícola. } \\
\text { Objetivos dos estudantes: } \\
\text { - Conhecer possibilidades de carreiras e formas de tornar os conteúdos trabalhados rentáveis. }\end{array}$ \\
\hline
\end{tabular}




\begin{tabular}{|c|c|}
\hline & $\begin{array}{l}\text { Orientações: } \\
\text { O objetivo dessa aula é introduzir as possíveis carreiras que os alunos podem seguir com o conteúdo que foi trabalhado } \\
\text { nessa SD, como Engenheiro ambiental, florestal, químico e Químico (entre outras profissões). Propõe-se, então, que } \\
\text { profissionais dessas áreas sejam chamados para darem depoimentos em sala de aula sobre a profissão por eles exercida. } \\
\text { Além disso, deve-se iniciar uma discussão que retoma o que é agricultura familiar (que já foi abordado ao longo da SD) e } \\
\text { apresentar possibilidades que a prática aprendida tem como forma de sustento, assim como fortalecer o que é uma boa } \\
\text { prática alimentar e incentivar os alunos a seguirem. Nesse contexto, deve-se retomar a discussão sobre o uso de } \\
\text { tecnologias na agricultura e o impacto social e econômico no mundo. Nos últimos } 5 \text { minutos da aula, o professor deve } \\
\text { levar os alunos até a horta experimental para discutir sobre mudanças que podem estar ocorrendo lá, assim como a } \\
\text { presença de insetos e outros rejeitos sobre a horta. }\end{array}$ \\
\hline $\begin{array}{lrr}\text { Aulas } \quad 7 & \text { e } & \text { 8: } \\
\text { Montagem } & & \text { dos } \\
\text { pôsteres } & & \\
\end{array}$ & $\begin{array}{l}\text { Atividade } 1 \text { - Construção do projeto final } \\
\text { - } \quad \text { Materiais } \\
\text { - } \quad \text { Cartazes; } \\
\text { - } \quad \text { Gípis de cor; } \\
\text { - Tinta; } \\
\text { - } \quad \text { Fotografias dos procedimentos impressas; } \\
\text { - Colas. } \\
\text { Objetivos da atividade: } \\
\text { - Construção dos pôsteres finais em formato de congresso científico. } \\
\text { Objetivos dos estudantes: } \\
\text { - Sintetizar em um pôster todos conhecimentos adquiridos ao longo da SD; } \\
\text { - } \quad \text { Compreender a estrutura de um pôster de divulgação científica; } \\
\text { - } \quad \text { Expressar a criatividade; } \\
\text { - Resolver uma situação de contexto ambiental como conclusão. } \\
\text { Orientações: } \\
\text { No início da primeira aula, o professor deverá levar os alunos para a última coleta de dados da horta. } \\
\text { Nessas duas aulas, os alunos irão confeccionar os pôsteres deles com imagens das etapas que realizaram no plantio, o } \\
\text { resultado até o momento e uma introdução (atividade que eles já realizaram). É importante antes de iniciar essa confecção } \\
\text { que o professor apresente aos alunos a estrutura que eles devem confeccionar e fale da importância de construir nessa } \\
\text { sequência os pôsteres (introdução, objetivos, metodologia, resultados e discussões e conclusão). O professor pode levar } \\
\text { um cartaz já dividido nessas etapas certinho, porém não é obrigatório. Idealiza-se que um poster de congresso seja } \\
\text { apresentado. }\end{array}$ \\
\hline $\begin{array}{l}\text { Aula 9: Apresentação } \\
\text { dos pôsteres }\end{array}$ & $\begin{array}{l}\text { Atividade } 1 \text { - Apresentação dos pôsteres } \\
\text { Objetivos educacionais: } \\
\text { - Verificar a evolução dos alunos quanto aos conceitos apresentados ao longo da SD; } \\
\text { - } \quad \text { Analisar a oratória dos alunos; } \\
\text { Objetivos dos estudantes: } \\
\text { - Apresentar o pôster finalizado para a sala toda. } \\
\text { Orientações: } \\
\text { Será destinado um intervalo de } 30 \text { minutos para todas as apresentações, em que cada grupo irá até a frente da sala e irá } \\
\text { apresentar o que fez no poster e porque fez cada parte. } \\
\text { Atividade } 2 \text { - Colheita } \\
\text { Objetivos educacionais } \\
\text { • Ensinar os alunos a colherem as hortaliças plantadas. } \\
\quad \text { Objetivos dos estudantes: }\end{array}$ \\
\hline
\end{tabular}


Research, Society and Development, v. 10, n. 5, e34110515024, 2021

(CC BY 4.0) | ISSN 2525-3409 | DOI: http://dx.doi.org/10.33448/rsd-v10i5.15024

\begin{tabular}{|c|c|}
\hline & $\begin{array}{l}\text { • Colher as hortaliças. } \\
\text { Orientaçães: } \\
\text { Os alunos deverão ser levados para a horta, onde irão aprender como colher e irão realizar a colheita das hortaliças } \\
\text { plantadas. Parte das hortaliças irão para a cantina da escola e outra parte delas irá ser distribuídas entre os alunos para que } \\
\text { eles levem para casa e entendam o que é um bom hábito alimentar. Além disso, será liberado um espaço para os alunos } \\
\text { que queiram plantar mais hortaliças, gerando assim uma produção de hortaliças que, futuramente, será uma fonte de renda } \\
\text { para a escola e fonte de alimentação para os alunos. }\end{array}$ \\
\hline $\begin{array}{l}\text { Aula 10: Finalização } \\
\text { da SD }\end{array}$ & 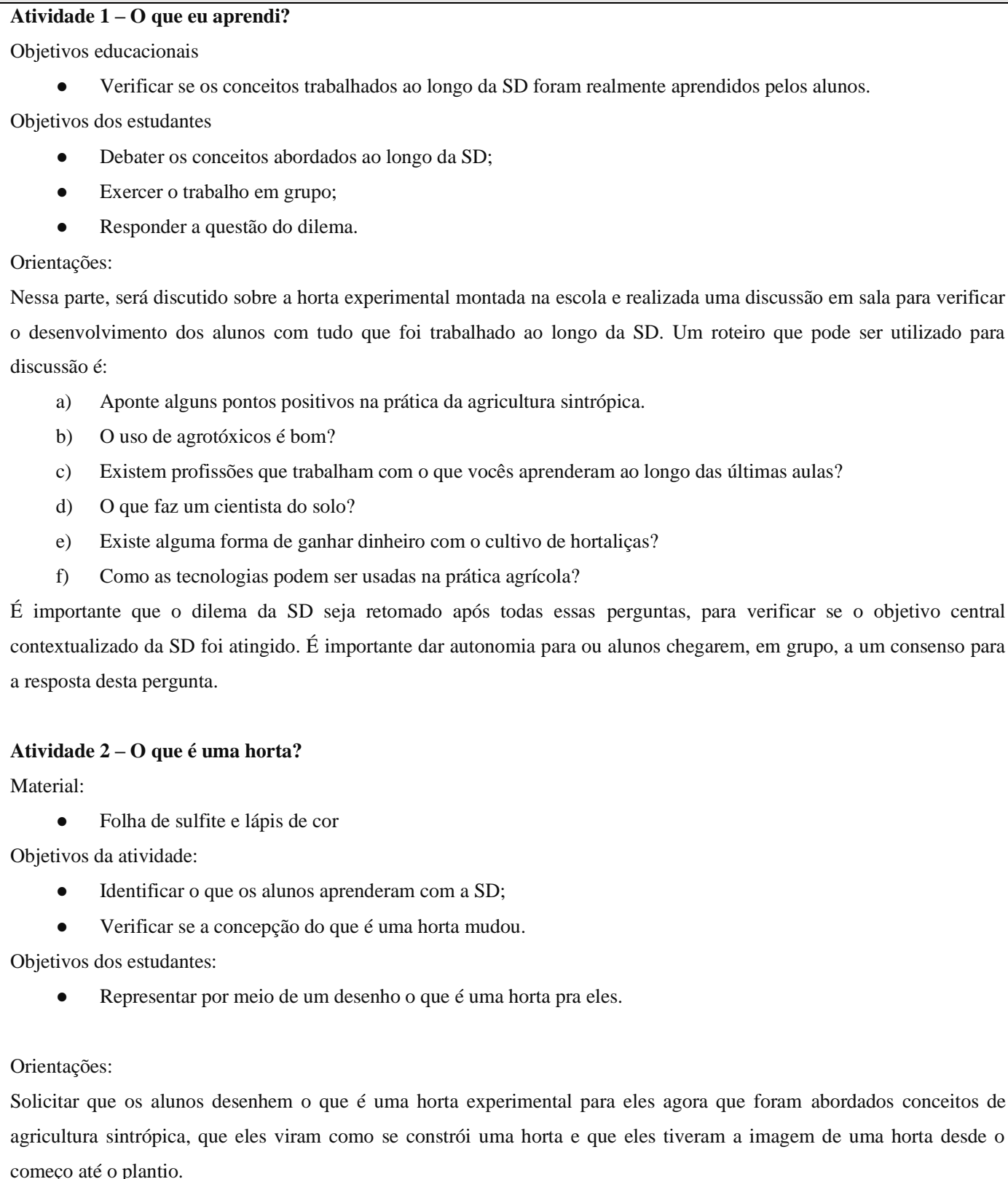 \\
\hline
\end{tabular}

Fonte: Os autores (2021).

Além do Quadro 3 proposto como mapa de atividades para o professor utilizar a sequência didática que apresenta as principais estratégias de ensino, todos materiais necessários e uma descrição de como as atividades podem ser aplicadas, elaborou-se um roteiro para os alunos que está representado na Figura 1. 
Figura 1: Roteiro para os alunos como material complementar à SD.

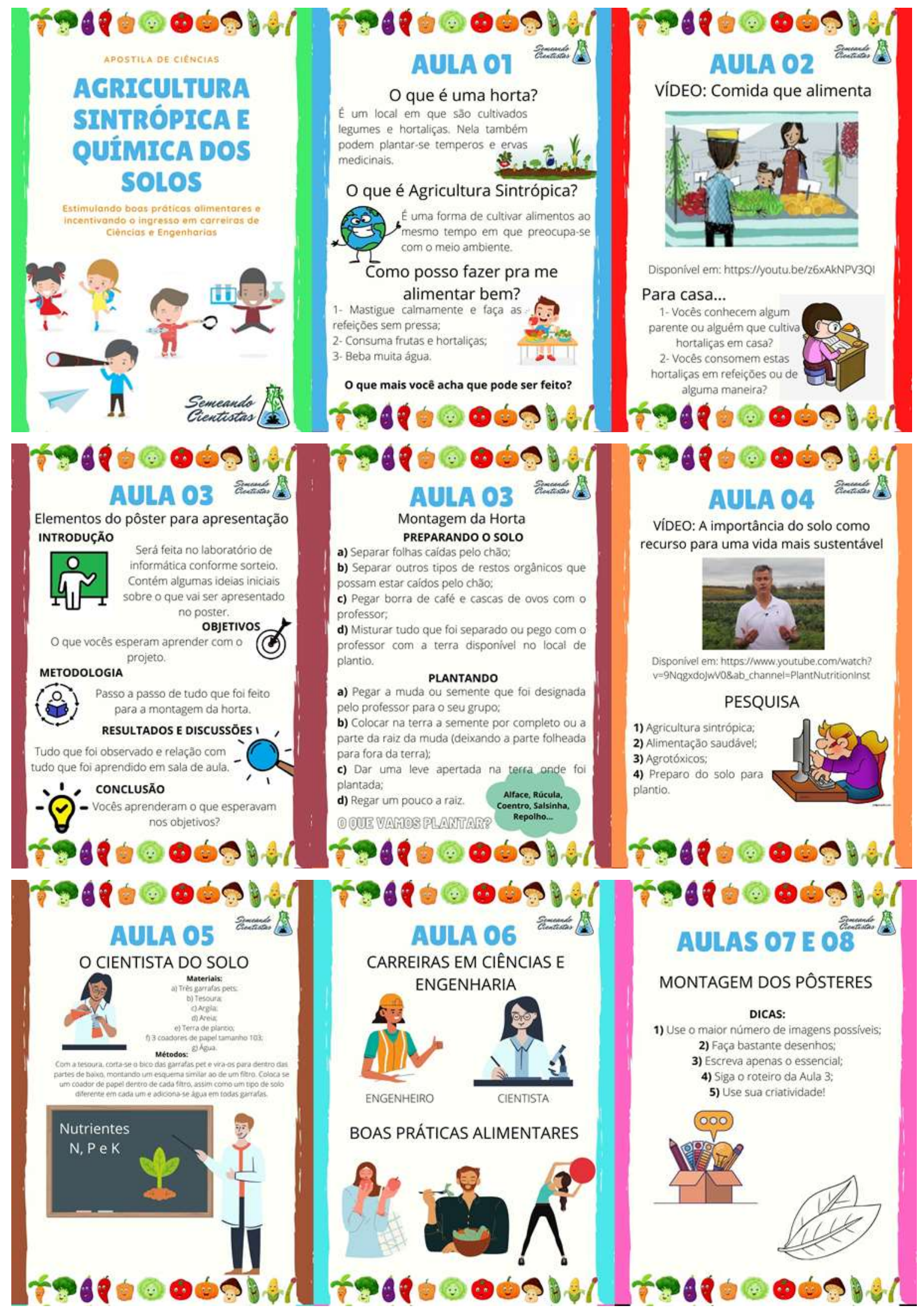




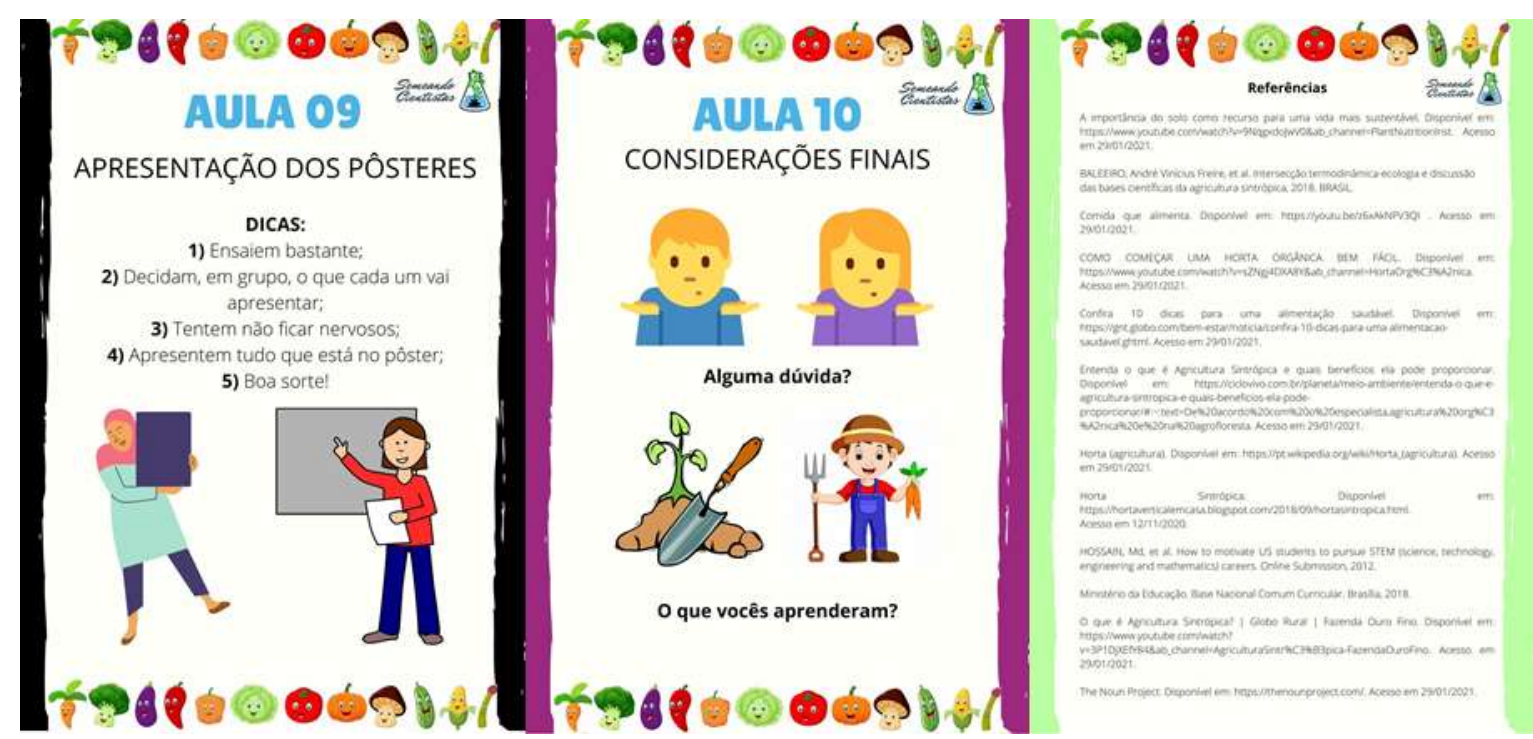

Fonte: Os autores (2021).

Como observa-se na Figura 1, foi construído um material didático para os alunos que apresenta imagens que podem atrair a atenção deles e com um aporte teórico que permite o acompanhamento de todas atividades que estão descritas no Quadro 3. O Quadro 4 apresenta os principais recursos, tecnologias emergentes e estratégias adotadas para a aplicação da SD, como forma de resumir os materiais necessários que foram apresentados ao longo do Quadro 3.

Quadro 4: Principais recursos, tecnologias e estratégias adotadas para a aplicação da SD.

\begin{tabular}{|l|l|}
\hline Recursos didáticos & Cartazes, materiais de colorir, materiais de colagem, projetor, câmeras, internet. \\
\hline $\begin{array}{l}\text { Tecnologias } \\
\text { emergentes }\end{array}$ & $\begin{array}{l}\text { Será preciso um laboratório de informática com computadores com acesso à internet para } \\
\text { aplicar essa SD. }\end{array}$ \\
\hline Estratégias adotadas & $\begin{array}{l}\text { Reprodução de vídeos, promoção de discussões em sala de aula, pesquisas orientadas, } \\
\text { dinâmica, resoluções de problemas e construção de pôsteres. }\end{array}$ \\
\hline
\end{tabular}

Fonte: Os autores (2021).

Logo, nota-se pela observação do Quadro 4 a utilização de diferentes recursos para atingir um aprendizado mais significativo, a abordagem de tecnologias com a finalidade de realização de pesquisas e o uso de diferentes estratégias que podem ser uma motivação para os alunos se manterem interessados no conteúdo da SD, a qual foi desenvolvida voltada para a realidade das crianças que nosso grupo de pesquisa já apresenta experiência de trabalho.

\subsection{Análise da SD}

\subsubsection{Metodologia STEM e Competências da BNCC}

A metodologia de ensino STEM apresenta-se ao longo da SD de diferentes formas. Nas Aulas 5 e 6 em que são propostos, respectivamente, um experimento e uma feira de profissões para os alunos, nota-se a presença da metodologia de ensino STEM ao realizar a montagem de um experimento e, depois, exemplificar conceitos que englobam aquele experimento de forma contextualizada ou ao propor um contato entre as crianças e profissões das carreiras de ciência, tecnologia, engenharia e matemática.

Porém a aplicação da metodologia STEM vai além, pois ela baseia-se na substituição do ensino tradicional por abordagens baseadas em projetos e pesquisas (Breiner, et al., 2012), como a atividade central da SD em que os alunos terão de desenvolver um projeto de caráter científico sobre química dos solos e aprender como apresentar os dados que serão 
desenvolvidos nesse projeto, tendo de fazer pesquisas em laboratório de informática, refletir sobre os objetos de estudo abordados nas aulas teóricas e conciliar o conhecimento adquirido com o objetivo final da SD.

Essa metodologia proporciona uma forma mais ativa de os alunos desenvolverem habilidades e práticas que se relacionam com as competências gerais da $\mathrm{BNCC}$, como pensamento científico, crítico e criativo, comunicação, responsabilidade e cidadania e até mesmo começar a refletir sobre trabalho e projeto de vida (BNCC, 2018).

As competências sobre comunicação e pensamento científico, crítico e criativo mostram-se mais presentes ao longo de todas as etapas da atividade do projeto principal da SD. A competência de responsabilidade e cidadania é discutida ao levar em consideração aspectos sociais e a realidade para qual a SD destina-se (crianças em situação de vulnerabilidade socioeconômica), trabalhadas principalmente na aula 1 e 2 quando são discutidas a importância de se alimentar bem, enquanto a competência de trabalho e projeto de vida é discutida na aula 6 com a feira de profissões em que são apresentadas possibilidades de carreiras em ciências e engenharia a partir dos conceitos que são trabalhados ao longo da SD.

Além disso, a sequência didática apresenta uma dinâmica (Atividade 2 -aula 6 - dinâmica das folhas) que é extremamente importante de ser aplicada com os alunos, pois ela trabalha uma competência geral da BNCC que merece um destaque: a empatia e cooperação. De acordo com a Base Nacional Comum Curricular (2018), a competência de empatia e cooperação é para "exercitar a empatia, o diálogo, a resolução de conflitos e a cooperação, fazendo-se respeitar e promovendo o respeito ao outro e aos direitos humanos, com acolhimento e valorização da diversidade de indivíduos e de grupos sociais, seus saberes, identidades, culturas e potencialidades, sem preconceitos de qualquer natureza" e tem como objetivo "fazer-se respeitar e promover o respeito ao outro e aos direitos humanos, com acolhimento e valorização da diversidade, sem preconceito de qualquer natureza".

A dinâmica das folhas torna-se interessante pelo fato de abrir espaço para uma discussão sobre a individualidade de cada criança, fazendo-as refletir sobre respeito aos outros e sobre o acolhimento e individualidade de indivíduos. Essa discussão fortalece uma educação reflexiva, buscando a quebra de preconceitos e fazendo com que os alunos comecem a despertar uma valorização pela diversidade.

O momento em que as competências específicas foram abordadas ao longo da SD podem ser resumidos pelo Quadro 5, o qual apresenta as habilidades expressas no Quadro $1 \mathrm{e}$ correlaciona com as atividades desenvolvidas ao longo da sequência didática.

Quadro 5: Habilidades específicas da BNCC e momento em que são apresentadas na sequência didática.

\begin{tabular}{|c|c|}
\hline Habilidade & Apresentação na SD \\
\hline $\begin{array}{l}\text { (EF02CI04) Descrever características de } \\
\text { plantas e animais (tamanho, forma, cor, fase } \\
\text { da vida, local onde se desenvolvem etc.) que } \\
\text { fazem parte de seu cotidiano e relacioná-las } \\
\text { ao ambiente em que eles vivem. }\end{array}$ & $\begin{array}{l}\text { A dinâmica das folhas (Atividade } 2-\text { Aula 5) proporciona o } \\
\text { desenvolvimento desta habilidade ao permitir que os alunos reflitam sobre } \\
\text { as diferentes características de folhas e em como o cientista do solo pode } \\
\text { trabalhar para diferenciar as folhas que elas colheram ao longo da } \\
\text { dinâmica. }\end{array}$ \\
\hline $\begin{array}{l}\text { (EF03CI09) Comparar diferentes amostras de } \\
\text { solo do entorno da escola com base em } \\
\text { características como cor, textura, cheiro, } \\
\text { tamanho das partículas, permeabilidade etc. }\end{array}$ & $\begin{array}{l}\text { O experimento sobre os tipos de solos (Atividade } 1 \text { - Aula 5) permite } \\
\text { abertura para a discussão desta habilidade, assim como a dinâmica das } \\
\text { folhas. O experimento permite refletir sobre características dos solos } \\
\text { (permeabilidade, cor, textura) enquanto a dinâmica permite a discussão } \\
\text { sobre onde as folhas são encontradas e características delas. Além disso, o } \\
\text { projeto principal da construção de uma horta com os conceitos de sintropia } \\
\text { relaciona-se diretamente com esta habilidade, fomentando a discussão } \\
\text { sobre como preparar o solo e a importância desta atividade. }\end{array}$ \\
\hline
\end{tabular}




\begin{tabular}{|c|c|}
\hline $\begin{array}{l}\text { (EF05CI08) Organizar um cardápio } \\
\text { equilibrado com base nas características dos } \\
\text { grupos alimentares (nutrientes e calorias) e } \\
\text { nas necessidades individuais (atividades } \\
\text { realizadas, idade, sexo etc.) para a } \\
\text { manutenção da saúde do organismo. }\end{array}$ & $\begin{array}{l}\text { As discussões realizadas ao longo da SD sobre como se alimentar bem } \\
\text { proporcionam o desenvolvimento desta habilidade. Além disso, os alunos } \\
\text { trabalham efetivamente esta habilidade ao iniciarem o cultivo de uma horta } \\
\text { com os conceitos de sintropia e identificarem, na prática, a importância da } \\
\text { atividade que eles estão realizando para a manutenção da saúde e as } \\
\text { contribuições que os nutrientes podem apresentar. }\end{array}$ \\
\hline $\begin{array}{l}\text { (EF07CI06) Discutir e avaliar mudanças } \\
\text { econômicas, culturais e sociais, tanto na vida } \\
\text { cotidiana quanto no mundo do trabalho, } \\
\text { decorrentes do desenvolvimento de novos } \\
\text { materiais e tecnologias (como automação e } \\
\text { informatização). }\end{array}$ & $\begin{array}{l}\text { Esta habilidade é desenvolvida ao longo da SD na Aula } 6 \text { em que serão } \\
\text { discutidas profissões que apresentam relação com a SD e serão discutidas o } \\
\text { uso de tecnologias na prática agrícola, proporcionando a discussão e } \\
\text { avaliação do impacto que esse uso gera economicamente e socialmente. }\end{array}$ \\
\hline $\begin{array}{l}\text { (EF06MA32) Interpretar e resolver situações } \\
\text { que envolvam dados de pesquisas sobre } \\
\text { contextos ambientais, sustentabilidade, } \\
\text { trânsito, consumo responsável, entre outros, } \\
\text { apresentadas pela mídia em tabelas e em } \\
\text { diferentes tipos de gráficos e redigir textos } \\
\text { escritos com o objetivo de sintetizar } \\
\text { conclusões. }\end{array}$ & $\begin{array}{l}\text { O projeto da construção de um poster com a estrutura de um painel de } \\
\text { congresso (contendo introdução, objetivos, metodologia, resultados e } \\
\text { discussões e conclusão) proporciona o desenvolvimento desta habilidade, } \\
\text { ao permitir o contato dos alunos com a análise de dados que serão } \\
\text { provenientes da horta construída. Os dados serão obtidos de um ambiente } \\
\text { dentro da realidade dos alunos em forma de variações de tamanho das } \\
\text { plantas, diferentes características, tempo de crescimento e outras } \\
\text { observações e poderão ser apresentados na forma de tabelas e gráficos, ou } \\
\text { mesmo serem redigidos como textos escritos. }\end{array}$ \\
\hline
\end{tabular}

Fonte: Os autores (2021).

O Quadro 5 fornece uma visão sobre em quais atividades da SD proposta são desenvolvidas cada competência da BNCC e o porquê essa competência é desenvolvida, sendo um parâmetro a ser observado caso se queira realizar alterações nas atividades que foram propostas, buscando sempre atingir as mesmas competências, porém sendo um parâmetro sobre quais partes da SD podem ser alteradas para acréscimo de outras competências da BNCC sem prejuízo das competências que já foram propostas no nosso trabalho.

\subsubsection{Abordagem CTS na construção da SD}

A construção da sequência didática engloba, ao longo de suas etapas, elementos que se relacionam com ciência, tecnologia e sociedade, podendo ambos serem desenvolvidos em uma etapa da SD. A abordagem CTS busca que os alunos, além de terem acesso a informações sobre o conhecimento científico-tecnológico, possam ter condições de avaliar e tomar decisões que podem atingir o meio que eles vivem (Pinheiro, et. al., 2007).

A abordagem CTS utilizada com subsídio para a construção da SD permite que os alunos construam uma visão crítica da ciência e participem da sociedade, assim como estejam aptos a realizarem tomadas de decisões, conforme relatado nos trabalhos de Santos e colaboradores (2000).

Nessa abordagem, o processo de ensino-aprendizagem passa a ser uma possibilidade de despertar algumas características nos alunos como curiosidade, espírito investigador, questionador e transformador da realidade (Pinheiro, et. al., 2007). Segundo Teixeira e colaboradores (2003), a abordagem CTS segue uma estrutura característica: introdução de uma questão social, análise de uma tecnologia associada a questão social, definição de conceitos e habilidades científicas relacionadas a questão social introduzida e tecnologia associada, retomada da tecnologia em função dos novos conceitos trabalhados e retomada da questão social na busca por soluções. 
A introdução de uma questão social é apresentada nas aulas 1 e 2, as quais discutem o dilema da SD, apresentam uma discussão sobre o uso de agrotóxicos e introduzem o que é uma horta. Por sua vez, as discussões são realizadas com base no tema da SD (química dos solos e agricultura sintrópica), abrangendo discussões sobre as vivências dos alunos e que fazem do uso de ciência e tecnologia, fato que pode ser correlacionado como as inter-relações CTS compreendidas por Firme e colaboradores (2011) como "domínios distintos que se influenciam mutuamente na construção de conhecimentos, e que tanto promovem modificações nas formas de vida da sociedade, como podem ser influenciadas por esta sociedade através de políticas públicas".

A análise de uma tecnologia associada a questão social é apresentada na aula 4, em que são apresentados os fundamentos da agricultura sintrópica e a importância dela, já que esta é uma maneira de minimizar um problema social relacionado à degradação do meio ambiente, mais especificamente do solo que cada vez fica mais pobre pelo fato do uso de fertilizantes e agrotóxicos. Ainda nessa aula, busca-se que os alunos façam pesquisa em laboratório sobre tópicos que serão pré-determinados para a construção da introdução do projeto final, permitindo a correlação entre o uso de tecnologias, as tecnologias associadas a questão social e os objetos de estudo que foram apresentados dentro desta aula.

A definição de conceitos e habilidades científicas relacionadas a questão social introduzida e tecnologia associada é apresentada na aula 5, a qual refere-se ao estudo do solo e do trabalho realizado pelo cientista do solo, assim como o desenvolvimento dos alunos como seres humanos, trabalhando a empatia e a cooperação. Nesta aula, apresenta-se o principal objeto de estudo em termos de conceitos químicos (o solo) e suas características, como permeabilidade e cor. O uso de experimento e dinâmica nesta aula torna o estudo mais atrativo para os alunos, podendo gerar um melhor aprendizado por conta de não tratar mais o aluno apenas como um receptor de conteúdos e sim como personagem ativo na construção do processo ensino-aprendizagem.

A retomada da tecnologia em função dos novos conceitos trabalhados é apresentada na aula 6, em que são discutidas as profissões que englobam os conhecimentos que são apresentados ao longo da SD e o uso de tecnologias na prática agrícola. Com essa aula, os alunos passam a entender que a questão social inicialmente proposta relaciona-se diretamente com o uso de tecnologias e passa a enxergar a tecnologia como meio para construção de novos conhecimentos e melhoria da qualidade de vida humana.

A retomada da questão social na busca por soluções é apresentada na última aula da SD (aula 10), momento no qual é realizado uma discussão com os alunos em sala de aula sobre os conhecimentos trabalhados na SD, é proposto que eles refaçam a atividade da aula 1 sobre o que é uma horta para eles e é discutido e proposto, em grupo, uma solução para o dilema da SD que foi apresentado na primeira aula. A resolução do dilema é uma resposta obtida por meio da construção coletiva dos alunos, não apresentando certo ou errado, mas levando em consideração tudo que foi trabalhado na SD, a metodologia de ensino aplicada (STEM), as competências da BNCC que buscou-se desenvolver e a abordagem CTS que foi usada para construção da SD.

Além disso, o material desenvolvido para os estudantes (Figura 1) torna o processo de ensino-aprendizagem mais lúdico e fornece uma maior independência para os alunos na tomada de decisões, tendo em vista que eles participarão ativamente da construção de quase todas as atividades propostas e deverão, olhando o roteiro, refletir sobre qual o melhor caminho para a realização de todas atividades. Esse material também apresenta algumas dicas que são importantes para o desenvolvimento de habilidades como oratória e para a apresentação de conhecimentos sobre divulgação científica e sua importância ao mesmo tempo em que os alunos estão produzindo o conhecimento científico e atuando como, de certa forma, cientistas.

O material acompanha aula a aula o que o professor está propondo como atividade e pode ser utilizado juntamente das aulas para fomentar uma discussão acerca dos objetos de conhecimentos que serão discutidos em cada aula. Outra contribuição 
que o material apresenta é a da reprodutibilidade das atividades desenvolvidas pelos alunos em ambientes fora da escola, indo ao encontro a uma das propostas que é desenvolver nos alunos a ideia de que a agricultura pode ser também uma fonte de renda e de boas práticas alimentares.

Após a finalização da SD, espera-se que os alunos estejam aptos a aplicar os conhecimentos adquiridos na casa deles e possam, por exemplo, construir uma horta na caseira aplicando os conceitos de agricultura sintrópica estudados. Essa possibilidade de construção da horta torna-se relevante ao contexto da SD por visar desenvolver em crianças que se encontram em situação de vulnerabilidade socioeconômica a importância de boas práticas alimentares, relacionar com os conceitos de ciências aprendidos e demonstrar a aplicação direta e importância de tudo que foi estudado no cotidiano. Além disso, a aplicação da SD permite o envolvimento dos familiares que podem, eventualmente, iniciar a construção de uma horta e comercializar as verduras produzidas, gerando uma renda para família.

A presente SD ainda não foi aplicada devido ao cenário mundial pandêmico ocasionado pela COVID-19, podendo ser adaptada ao longo de sua aplicação e das dificuldades que possam aparecer, como falta de materiais e falta de recursos. A avaliação da SD será realizada de maneira gradual, de acordo com as discussões apresentadas em sala de aula e o desempenho no projeto final que busca colocar os alunos em contato com a divulgação científica.

\section{Conclusão}

A construção da sequência didática tendo como base a química dos solos e o uso da agricultura sintrópica é uma alternativa para apresentação desse conteúdo dentro de sala de aula, tendo em vista que ele não é comumente apresentado dentro dos currículos das escolas. O uso da metodologia STEM potencializa os conceitos da abordagem CTS devido ao fato de o STEM buscar a resolução de projetos e problemas enquanto a abordagem CTS focaliza na tomada de decisões por parte dos alunos, ou seja, essa combinação é aplicável como um diferencial na construção da SD.

A SD conta com o desenvolvimento de competências gerais e específicas da Base Nacional Comum Curricular, justificando a destinação dela ao público alvo de 11 a 14 anos mesmo que os conceitos de química não sejam diretamente trabalhados nos currículos correspondentes a essa faixa etária (Fundamental II).

O projeto final potencializa o aprendizado devido ao fato de exigir ativamente a participação dos alunos ao mesmo tempo que os coloca em contato com a aplicação do conteúdo trabalhado dentro do cotidiano. Todas as atividades relacionamse com as competências da BNCC trabalhadas para a formação do aluno, tornando a SD aplicável e um diferencial devido ao fato de pouco se apresentar hoje em dia sobre química dos solos ao longo da formação das crianças do ensino fundamental e jovens do ensino médio.

Além disso, a SD conta como uma forma de incentivar os alunos a apresentarem boas práticas alimentares, despertarem interesse em carreiras de ciências e tecnologias, desenvolverem competências relacionadas com empatia e cooperação e mostra-se como uma alternativa aplicável para o ensino de química dos solos para alunos do ensino fundamental.

Trabalhos futuros relacionados ao nosso trabalho destinam-se a construção de uma SD que possa ser aplicada de forma remota devido a situação atual mundial. Além disso, quando a situação se normalizar, a presente SD será aplicada no Centro de Apoio Nossa Senhora do Sagrado Coração, dando continuidade a proposta do projeto Semeando Cientistas.

\section{Referências}

Baleeiro, A. V. F., et al (2018). Intersecção termodinâmica-ecologia e discussão das bases científicas da agricultura sintrópica.

Breiner, J. M.,Harkness, S. S., Johnson, C. C., \& Koehler, C. M. (2012). What is STEM? A discussion about conceptions of STEM in Education and Partnerships. School Science and Mathematics, 11 (1), 1-11. 
Carnevale, A. P.,Smith, N., \& Melton, M. (2011). STEM: Science Technology Engineering Mathematics. Education Resources Information Center, Georgetown, $112 \mathrm{p}$.

Cribb, S. (2010). Contribuições da educação ambiental e horta escolar na promoção de melhorias ao ensino, à saúde e ao ambiente. Ensino, Saúde e Ambiente Backup, 3(1).

Dolz, J., Noverraz, M., \& Schneuwly, B. (2004). Sequências didáticas para o oral e para o escrito: apresentação de um procedimento. Gêneros orais e escritos na escola. Campinas, SP: Mercado de Letras, $95-128$.

Firme, R. do N., \& Amaral, E. M. R. do. (2011). Analisando a implementação de uma abordagem CTS na sala de aula de química. Ciência \& Educação (Bauru), 17(2), 383-399. https://dx.doi.org/10.1590/S1516-73132011000200009.

Francisco, C. N. P. (2018). A difusão de novas competências pela bncc: os multiletramentos e o ensino da linguagem na era das novas tecnologias. Anais do $16^{\circ}$ Congresso Internacional de Tecnologia na Educação, Recife.

Hossain, M. D., et al. (2012). How to motivate US students to pursue STEM (science, technology, engineering and mathematics) careers. Online Submission. https://eric.ed.gov/?id=ED533548.

Instituto Ayrton Senna (2015). O que é BNCC. São Paulo. https://institutoayrtonsenna.org.br/pt-br/BNCC/o-que-e-BNCC.html.

Ministério da Educação. Base Nacional Comum Curricular. Brasília.

Morrison, J. S. (2006). STEM education: The student, the school, the classroom. TIES STEM Education Monograph Series, 1 - 7 . http://www.leadingpbl.org/f/Jans\%20pdf\%20Attributes_of_STEM_Education-1.pdf.

Peneireiro, F. M. (1999). Sistemas agroflorestais dirigidos pela sucessão natural: um estudo de caso. Esc Peneireiroola Superior de agricultura "Luiz de Queiroz.

Pinheiro, N. A. M., Silveira, R. M. C. F., \& Bazzo, W. A. (2007). Ciência, Tecnologia e Sociedade: a relevância do enfoque CTS para o contexto do Ensino Médio. Ciência \& Educação (Bauru), 13(1), 71-84. https://doi.org/10.1590/S1516-73132007000100005.

Pereira A. S., et al. (2018). Metodologia da pesquisa científica. [free e-book]. Santa Maria/RS. Ed. UAB/NTE/UFSM.

Ramalho Junior, R. R., Silva, M. R. A. da., \& Oliveira, J. R. S. de (2020). Soil Chemistry: production of a didatic Sequence based on science, technology and society approach. Research, Society and Development, 9(11). https://doi.org/10.33448/rsd-v9i11.9811

Santos, W. L. P. (2007). Contextualização no ensino de ciências por meio de temas CTS em uma perspectiva crítica. Ciência \& Ensino, 1, número especial.

Santos, W. L. P. (2008). Contextualização no ensino de ciências por meio de temas CTS em uma perspectiva crítica. Ciência \& Ensino), 1.

Santos, W. L. P., \& Mortimer, E. F. (2000). Uma análise de pressupostos teóricos da abordagem CTS (Ciência-Tecnologia-Sociedade) no contexto da educação brasileira. Ensaio Pesquisa em educação em ciências, 2(2), 1-23.

Santos, W. L. P., \& Mortimer, E. F. (2001). Tomada de decisão para ação social responsável no ensino de ciências. Ciência \& Educação (Bauru), 7(1), 95111.

Souza, S. N. S., \& Nunes, M. A. D. (2018). Horta na escola e suas contribuições na promoção da saúde, alimentação saudável e preservação ao meio ambiente. Educação ambiental em ação, XVI(63).

Teixeira, P. M. M. (2003). A educação científica sob a perspectiva da pedagogia histórico-social e do movimento CTS no ensino de ciências. Ciência \& Educação, Bauru. 9(2), 177-190. 